\title{
線形逆散乱解析による多孔質弾性体中の不均質部の形状再構成
}

\author{
山本 晃 司*.北原道 弘**
}

\section{Shape reconstruction of scatterers in poroelastic media using linearized inverse scattering analysis}

\author{
Koji Yamamoto* and Michihiro Kitahara**
}

\begin{abstract}
The Linearized Inverse Scattering Analysis using Born approximation is applied to the Biot's Poroelastic model for the visualization of scatterers in porous media. Spatial and frequency distribution of the scattering amplitude is used for the shape reconstruction of a scatterer in which solid frame and/or pore fluid properties are different from surrounding media. The inversion method is based on the field integral expression of the scattered field, its linearization by Born approximation, and a direct inversion method by using the Inverse Fourier Transform. In this paper, theoretical background and numerical formulations of the method are described, and some examples of the reconstructed form of scatterers using simulated scattered field are shown. The examples show the applicability of the inversion method to the fluid filled porous material. The limited aperture problem is also discussed using the numerical results. It is shown that the reconstruction of scatterer geometry is still available with some degree of the lack of information.
\end{abstract}

Key words: biot, poroelasticity, inversion, born approximation

\section{1. はじめに}

資源開発や環境問題では逆解析手法による地層中の物 性値分布のイメージングが課題となっており，特に流体 挙動のモニタリングは重要な問題である。そのための手 法として坑井間トモグラフィなどの弾性波を用いた技術 が使われていて, EOR (Nur and Wang, 1987 ; 横田ら， 2003), メタンハイドレートからのガス生産 (Bauer et al., 2004), 二酸化炭素の地中隔離（大下，2002）など の分野に適用されている。

これらで現在一般に用いられている手法は初動走時卜 モグラフィー (LaPorte et al., 1973) である。この手法 は, レイパスの理論に基づいて波の屈折・伝播の問題を 考え，観測した波の到達時刻や波形を再現するように，

2005年. 3 月 29 日原稿受付; 2005年. 11 月 18 日受理 物理探査学会第110回（王成16年度春季）学術講演会で一 部を発表

* 東北大学大学院工学研究科土木工学専攻 980-8579 仙台市青葉区.荒巻字青葉 6-6-06 (現 独石油天然ガス・金属鉱物資源機構)

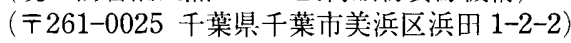

** 東北大学大学院工学研究科土木工.学専攻 980-8579 仙台市青葉区荒巻字青葉 6-6-06

(C)2005 SEGJ
速度構造の最適解を求めるものである。この手法は波長 が不均質部のスケールよりも短い場合に成立する高周波 近似であるといえる。

さらに散乱波動場も考慮した波形情報を用いた最適化 を四るフルウェーブインバージョン (Pratt and Worthington, 1990; Pratt, 1999) の手法があり, 最急降下法 等の収束計算によって速度構造の最適解を求めている。 それに対して, 本論文で扱う線形逆散乱解析 (Linearized Inverse Scattering Analysis) は, 均質媒体中に置 かれた散乱体からの散乱波強度の空間及び周波数分布と 散乱体領域の形状を解析的に結びつけて再構成する逆解 析手法である (Rose and Opsal, 1982; Hsu et al., 1984; Rose, 1984; Schmerr et al., 1989)。

本手法は, 弾性体の問題については定式化と同時に実

Manuscript received March 29, 2005; Accepted Novembar 18, 2005

A part of this paper was presented at the 110th SEGJ conference, 2004

* Tohoku University, Department of Civil Engineering Aoba 6-6-06, Sendai 980-8579, JAPAN

(Presently, Japan Oil, Gas and Metals National Corporation 1-2-2, Hamada, Mihama-ku, Chiba, Chiba 261-0025, Japan)

** Tohoku University, Department of Civil Engineering Aoba 6-6-06, Sendai $980-8579$, JAPAN 
験的検証も行われている (Kitahara and Hirose, 1998; Kitahara et al., 2002 ; 山田ら, 2003 ; 宮腰・山田, 2005）が，ここではこの手法を流体で飽和した多孔質 体に拡張する。間隙流体の影響を表現するために，Biot による飽和多孔質弾性体のモデル（Biot，1956; Biot, 1962）を用いて，固体骨格と間隙流体のいずれかある いは双方の物性が周囲と異なる領域を散乱体と考えて, 観測された散乱波からその形状を求める手法の数值的基 礎を示す。また，数值解析で得られた模擬的な散乱波を 利用して，間隙流体の物性が周囲と異なる領域の形状の 再構成が可能であることを示す。

\section{2. 散乱波動場の積分表現}

\subsection{Biot の多孔質弾性モデル}

本論文で間隙流体の影響をモデル化するために用いた Biotの多孔質弾性モデルは，空間が弾性体の粒子骨格 とその孔隙を飽和する圧縮性の間隙流体で構成され，粒 子，粒子骨格，および間隙流体の弾性係数とともに，多 孔質体の浸透率と流体の粘性が弾性波速度を定めると考 える。

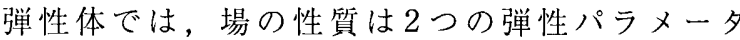
(Lamé 定数 $\mu, \lambda$ ) と 1 つの質量パラメータ（密度 $\rho$ ) で記述され，媒質の運動は三次元空間では 3 つの自由 度（変位：u）を持ち，2 種類の波（縦波及び横波）が 生じる。それに対して，Biotの多孔質弾性体を記述す るには，4つの弾性パラメー夕（骨格の Lamé 定数 $\mu$ 及 び $\lambda, \operatorname{Biot} の$ 有効忍力定数 $\alpha, \operatorname{Biot}$ の弾性定数 $M$ ) と, 2 つの質量パラメータ（全体系の密度 $\rho$ 及び流体密度 $\left.\rho_{f}\right)$ ，孔隙率 $(\boldsymbol{\beta})$ ，及び散逸に関わる定数 $(b)$ の 8 つ の独立したパラメータが必要で (Biot and Willis, 1957），空間の各点において流体の圧力 $p$ と固体の変位 $\boldsymbol{u}$ のつの自由度が現れる。

また多孔質弾性体を媒質とする波動には，横波(ここ では $T$-波と表す)，及び速い縦波と遅い縦波の 2 種類の 縦波（ここではそれぞれ L1-波とL2-波と表す）の 3 つ の波が現れ，孔隙間を移動する流体の流動抵抗によりエ ネルギーの散逸が生じ，それに伴い波速の分散性が生じ るという弾性体中の波とは異なる特徴が現れる（Biot， 1956; Biot, 1962)。Biot モデルによる波の性質について は狐崎 (2004), Yamamoto and Kitahara (2004) で詳 しく議論されている。

弾性体の Navier-Cauchy 方程式に対応する，均質な 多孔質弾性体における運動方程式は次のように書ける。

$$
L_{I J} q_{J}=-f_{I}
$$

ここで， $L_{I J}$ は微分演算子であり， $4 \times 4$ 要素の行列 $\left[L_{I J}\right]$ で表され，固体変位に関係する要素 $\left[L_{i j}\right]$ ，流体 厌少に関係する要素 $L_{44}$ ，及び相互の連成効果に関係す る要素 $\left\{L_{i 4}\right\}$ 及び $\left\{L_{4 j}\right\} \mathrm{T}$ のそれぞれからなる部分行列 に分けて次のように表すことができる（Yamamoto and
Kitahara, 2004)。

$$
\begin{aligned}
& {\left[L_{I J}\right]=\left[\begin{array}{ll}
{\left[L_{i j}\right]} & \left\{L_{i 4}\right\} \\
\left\{L_{4 j}\right\}^{\mathrm{T}} & L_{44}
\end{array}\right]}
\end{aligned}
$$

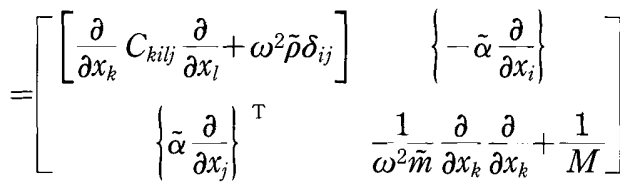

ここで，次の複素多孔質弾性パラメータを使用した。

$$
\tilde{m}=\frac{\rho_{f}}{\beta}-i b, \tilde{\alpha}=\alpha-\frac{\rho_{f}}{\tilde{m}}, \tilde{\rho}=\rho-\beta^{2} \tilde{m}
$$

また， $C_{k i l j}$ は固体骨格部に関する弾性テンソルで，

$$
C_{k i l j}=\lambda \delta_{k i} \delta_{l j}+\mu\left(\delta_{k l} \delta_{i j}+\delta_{k j} \delta_{l i}\right)
$$

と書ける。これ以降，大文字の添え字: $(I, J)$ は $1 \sim 4$ の值をとり，そのうち 1３はデカルト座標系の空間座 標を，また，4は流体圧力に関する項であることを示 す。小文字の添え字: $(i, j)$ は 1 3 の值をとり，空間座 標を示す。

また， $\boldsymbol{q}$ は固体の変位 $\boldsymbol{u}$ と流体圧力 $p$ より構成される 一般化された変位。 $\left(\boldsymbol{q}=\left\{\boldsymbol{u}^{\mathrm{T}}, p\right\}^{\mathrm{T}}\right)$ であり，また $\boldsymbol{f}$ は物 体力を示すべクトルで,

$$
\boldsymbol{f}=\left\{\left\{\rho b_{i}+\frac{\rho_{f}^{2}}{\tilde{m}} c_{i}\right\}^{\mathrm{T}}, \frac{\rho_{f}}{\omega^{2}} \tilde{m} c_{k, k}\right\}^{\mathrm{T}}
$$

と定義される。ここで， $\boldsymbol{b}, \boldsymbol{c}$ はそれぞれ単位質量の全体 系㧍よび流体に加わる物体才を示す。

\section{2 不均質部による散乱波動場}

次に，均質な多孔質弾性体の中に，その内部では均質 な局所的な不均質がある問題を考える。ここで，境界 $S$ によって册まれた閉領域 $D$ を考えると，運動方程式(1) の:.つの解 $\boldsymbol{q}=\left\{\boldsymbol{u}^{\mathrm{T}}, p\right\}^{\mathrm{T}}$ 及び $q^{*}=\left\{\boldsymbol{u}^{* T}, p^{*}\right\}^{\mathrm{T}}$ は相反定 理

$$
\int_{D}\left(f_{I} q_{I}^{*}-f_{I}^{*} q_{I}\right) d V=\int_{S}\left(s_{I}^{*} q_{I}-s_{I} q_{I}^{*}\right) d S
$$

を满たす (Schmerr, 1998)。ここで $(\boldsymbol{f}, \boldsymbol{s})$ 及び $\left(\boldsymbol{f}^{*}, \boldsymbol{s}^{*}\right)$ はそれぞれ解 $\boldsymbol{q}, \boldsymbol{q}^{*}$ に対応する物体力及び表面力を示す。

次に，Fig. 1 に示すように，一定の多孔質弾性パラ メー夕 $(\lambda, \mu, \tilde{\alpha}, 1 / M, 1 / \tilde{m})$ で定義された無限均質領域 $D$ (母:材) 中に，その内部では一定の物性值 $(\lambda+\Delta \lambda, \mu$ $+\Delta \mu, \tilde{\alpha}+\Delta \tilde{\alpha}, 1 / M+\Delta(1 / M), 1 / \tilde{m}+\Delta(1 / \tilde{m}))$ を持つ 不均質領域 $D^{c}$ (散乱体) が存在する状態を考える。領 域 $D$ 中の物性値の分布を表すために, 次の関数 $\Gamma(\boldsymbol{x})$ を導入する。 


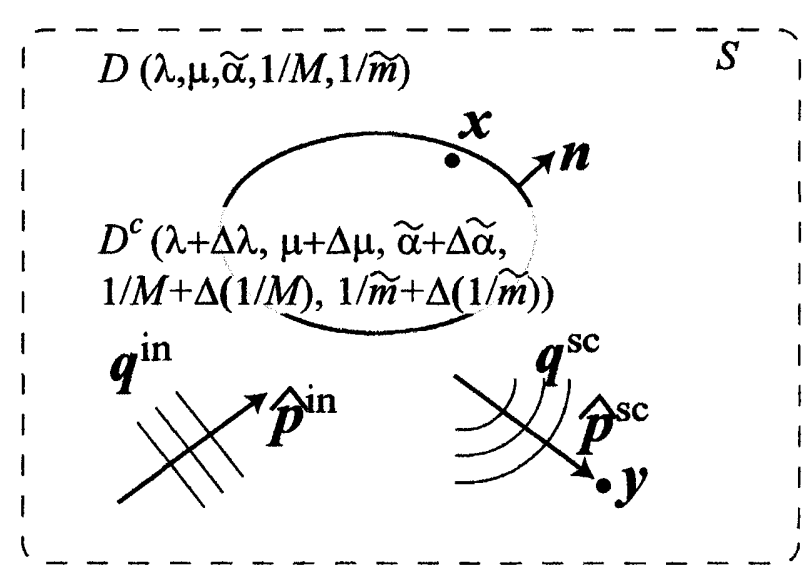

Fig. 1 Schematic of wave scattering by a scat-terer $D^{c}$ in a poroelastic medium $D$.

$$
\Gamma(\boldsymbol{x})= \begin{cases}1 & \text { for } \boldsymbol{x} \in D^{c} \\ 0 & \text { for } \boldsymbol{x} \in D \backslash D^{c}\end{cases}
$$

ただし，関数 $\Gamma(\boldsymbol{x})$ は領域 $D^{c}$ 及び $D \backslash D^{c}$ 内では一定値 であり， $D^{c}$ を囲む境界上では不連続となるが，便宜上 この境界上てで連続かつ 2 階微分可能であると考える。 この関数を䏘いると, 領域 $D$ 内の点 $\boldsymbol{x}$ に打ける任意の 物性値 $\phi$ は次のように表すことができる。

$$
\phi(\boldsymbol{x})=\phi+\Gamma(\boldsymbol{x}) \Delta \phi
$$

物体力が作用していないと考えた場合, 運動方程式 (1)はこの系に関して次のように書きなおせる。

$$
\begin{aligned}
& C_{i j k l} u_{k, l j}(\boldsymbol{x})-\tilde{\alpha} p_{, i}(\boldsymbol{x})+\tilde{\rho} \omega^{2} u_{i}(\boldsymbol{x}) \\
&=--\left[\Gamma(\boldsymbol{x}) \Delta \tilde{\rho} \omega^{2} u_{i}(\boldsymbol{x})\right. \\
&+\Delta C_{i j k l}\left\{\Gamma(\boldsymbol{x}) u_{k, l}(\boldsymbol{x})+\Gamma_{, j}(\boldsymbol{x}) u_{k, l}(\boldsymbol{x})\right\} \\
&\left.-\Delta \tilde{\alpha}\left\{\Gamma(\boldsymbol{x}) p_{, i}(\boldsymbol{x})+\Gamma_{, i}(\boldsymbol{x}) p(\boldsymbol{x})\right\}\right] \\
& \tilde{\alpha} u_{i, i}(\boldsymbol{x})+\frac{1}{\tilde{m} \omega^{2}} p_{, i i}(\boldsymbol{x})+\frac{1}{M} p(\boldsymbol{x}) \\
&=-\left[\Gamma(\boldsymbol{x}) \Delta\left(\frac{1}{M}\right) p(\boldsymbol{x})\right. \\
&+\Delta \tilde{\alpha}\left\{\Gamma(\boldsymbol{x}) u_{i, i}(\boldsymbol{x})+\Gamma_{, i}(\boldsymbol{x}) u_{i}(\boldsymbol{x})\right\}+\Delta\left(\frac{1}{\tilde{m}}\right) \frac{1}{\omega^{2}} \\
&\left.\times\left\{\Gamma(\boldsymbol{x}) p_{, i i}(\boldsymbol{x})+2 \Gamma_{, i}(\boldsymbol{x}) p_{, i}(\boldsymbol{x})+\Gamma_{, i i}(\boldsymbol{x}) p(\boldsymbol{x})\right\}\right]
\end{aligned}
$$

式(10) 及び(11)では不均質領域 $D^{c}$ に関係する項を右辺 にまとめているが，これらの項は式(1)の物体力 $\boldsymbol{f}$ に対 応していることがわかる。

この不均質部が波動場に与える影響を示すために, 次 に示す二:組の解を用いて式(7)の相反定理を書き直すこ とにする。

はじめの組は単位集中力 $\delta_{I N} \delta(\boldsymbol{x}-\boldsymbol{y})$ を物体力とした 場合の方程式の解の組であり，

$$
\left\{\begin{array}{l}
s_{i}=\left\{\lambda G_{k n, k} \delta_{i j}+\mu\left(G_{i n, j}+G_{j n, i}\right)-\alpha G_{4 n} \delta_{i j}\right\} n_{j} \\
s_{4}=\left(\frac{\rho_{f}}{\tilde{m}} G_{j 4}+\frac{1}{\omega^{2}} \tilde{m} G_{44, j}\right) n_{j} \\
q_{i}=G_{i N} \\
q_{4}=G_{4 N} \\
f_{i}=\delta_{i N} \delta(\boldsymbol{x}-\boldsymbol{y}) \\
f_{4}=\delta_{4 N} \delta(\boldsymbol{x}-\boldsymbol{y})
\end{array}\right.
$$

と書ける。ここで $\delta(\boldsymbol{x})$ はDiracのデル夕関数， $\delta_{i j}$ は Kroneckerのデルタである。また, $\left[G_{I J}\right]$ は，方程式：

$$
L_{I J} G_{J K}(\boldsymbol{x}, \boldsymbol{y})=-\delta_{I K} \delta(\boldsymbol{x}-\boldsymbol{y})
$$

の解で, 基本解と呼ばれる。また, $\boldsymbol{n}$ は $D^{c}$ の境界の外 向きの法線ベクトルである。基本解はCheng et al. (1991), Dominguez (1992), 福井ら (1996), Yamamoto and Kitahara (2004) が具体的に与えている。 本論文で用いたパラメー夕による基本解を補遺 1 に示 す。

もう一組の解は，不均質領域 $D^{c}$ の影響を物体力にお きかえた, 式 (10)及び(11)に対応する解の組であり,

$$
\left\{\begin{aligned}
s_{i}{ }^{*}= & \left\{\lambda u_{k, k} \delta_{i j}+\mu\left(u_{i, j}+u_{j, i}\right)-\alpha p \delta_{i j}\right\} n_{j} \\
s_{4}{ }^{*}= & \left(\frac{\rho_{f}}{\tilde{m}} u_{j}+\frac{1}{\omega^{2} \tilde{m}} p_{, j}\right) n_{j} \\
q_{i}{ }^{*}= & u_{i} \\
q_{4}{ }^{*}= & p \\
f_{i}{ }^{*}= & \Gamma(\boldsymbol{x}) \Delta \tilde{\rho} \omega^{2} u_{i}(\boldsymbol{x}) \\
& +\Gamma(\boldsymbol{x})\left\{\Delta C_{i j k l} u_{k, l}(\boldsymbol{x})-\Delta \alpha p, i(\boldsymbol{x})\right\} \\
& +\Gamma_{, j}(\boldsymbol{x})\left\{\Delta C_{i j k l} u_{k, l}(\boldsymbol{x})-\Delta \alpha p(\boldsymbol{x})\right\} \\
f_{4}{ }^{*}= & \Gamma(\boldsymbol{x}) \Delta\left(\frac{1}{M}\right) p(\boldsymbol{x}) \\
& +\Gamma(\boldsymbol{x})\left\{\Delta \tilde{\alpha} u_{i, i}(\boldsymbol{x})+\Delta\left(\frac{1}{\tilde{m}}\right) \frac{1}{\omega^{2}} p_{, i i}(\boldsymbol{x})\right\} \\
& +\Gamma_{, i}(\boldsymbol{x})\left\{\Delta \tilde{\alpha} u_{i}(\boldsymbol{x})+2 \Delta\left(\frac{1}{\tilde{m}}\right) \frac{1}{\omega^{2}} p_{, i}(\boldsymbol{x})\right\} \\
& +\Gamma_{, i i}(\boldsymbol{x}) \Delta\left(\frac{1}{\tilde{m}}\right) \frac{1}{\omega^{2}} p(\boldsymbol{x})
\end{aligned}\right.
$$

と書ける。

媒質 $D \backslash D^{c}$ 中の変位場 $\boldsymbol{q}$ は入射波 $\boldsymbol{q}^{\text {in }}$ 散乱波 $\boldsymbol{q}^{\mathrm{sc}}$ の 和で表される。そこで，これらの解を式(7)に代入し， 境界 $S$ を無限遠方 $S^{\infty}$ に拡大寸る。さらに, Sommerfeld の放射条件より無限遠方では散乱波は零 $\left(q^{\mathrm{sc}}=0\right)$ となることを利用して, 相反定理は次のように書き直せ る。

$$
q_{I}^{\mathrm{sc}}(\boldsymbol{y})=\int_{D} G_{I J}(\boldsymbol{x}, \boldsymbol{y}) B_{J}(\boldsymbol{x}) d V_{x}
$$

ただし，

$$
B_{i}(\boldsymbol{x})=\Gamma(\boldsymbol{x})\left[\Delta \tilde{\rho} \omega^{2} u_{i}(\boldsymbol{x})-\left\{\Delta C_{i j k l} u_{k, l}(\boldsymbol{x})\right.\right.
$$




$$
\begin{aligned}
& \left.\left.-\Delta \tilde{\alpha} p(\boldsymbol{x}) \delta_{i j}\right\} \frac{\partial}{\partial x_{j}}\right] \\
B_{4}(\boldsymbol{x})= & \Gamma(\boldsymbol{x})\left[\Delta\left(\frac{1}{M}\right) p(\boldsymbol{x})-\left\{\Delta \tilde{\alpha} u_{k}(\boldsymbol{x}) \frac{\partial}{\partial x_{k}}\right.\right. \\
& \left.\left.-\Delta\left(\frac{1}{\tilde{m}}\right) \frac{1}{\omega^{2}} p(\boldsymbol{x}) \frac{\partial}{\partial x_{k}} \frac{\partial}{\partial x_{k}}\right\}\right]
\end{aligned}
$$

である。式(15)，(16) 及び (17) から, 散乱波動場 $\boldsymbol{q}^{\mathrm{sc}}$ が, 領域 $D^{c}$ と $D \backslash D^{c}$ の多孔質弾性パラメータの差の領 域積分によって与えられることがわかる。ここで，Bを 等価散乱源と呼ぶこととする。また，ここでは $\Gamma(\boldsymbol{x})$ の微分に関する項は消去されて, 関数 $\Gamma(\boldsymbol{x})$ を連続か つ 2 階微分可能とした仮定の影響は現われないことが わかる。

\section{4 散乱振幅}

等価散乱源 $\boldsymbol{B}$ による遠力の散乱場を, 散乱波の種類 ごとに分離した形で求めるために，式(13)で定義され た基本解に遠方近似を導入した表現：

$$
G_{I J}^{\mathrm{far}}(\boldsymbol{x}, \boldsymbol{y})=\sum_{q=T, L 1, L 2} \tilde{g}_{I J}^{q}(\boldsymbol{x}, \hat{\boldsymbol{y}}) \frac{e^{i k_{q} r}}{r}
$$

を用いる (Yamamoto and Kitahara, 2003)。ここで, $q$ は散乱波の種類 $(q=T, L 1$ または $L 2)$ を示し, $k_{q}$ は $q-$ 波の波数を示す。また，rは散乱体と観測点 $\boldsymbol{y}$ の距離, $\hat{\boldsymbol{y}}$ は散乱体から観測点 $\boldsymbol{y}$ に向く力向ベクトルを示す。式 (18)における $\tilde{g}_{I f} f^{f}(\boldsymbol{x}, \hat{\boldsymbol{y}})$ の具体的な表現は補遺 2 に示 す。散乱体半径の $4 \sim 5$ 倍の位置で計測する場合, 遠方 近似は十分精度良く成立する。

式 (16)及び (17)より，等価散乱源 $\boldsymbol{B}$ による遠方の散 乱場 $q^{\mathrm{sc}(\mathrm{far})}$ は次のように書くことができる。

$$
\begin{aligned}
q_{I}^{\mathrm{sc}(\mathrm{far})}(\boldsymbol{y}) & =\int_{D} G_{I J}^{\mathrm{far}}(\boldsymbol{y}) B_{J}(\boldsymbol{x}) d V_{x} \\
& =\sum_{q=T, L 1, L 2} \int_{D} \tilde{g}_{I J}^{q}(\boldsymbol{x}, \hat{\boldsymbol{y}}) B_{J}(\boldsymbol{x}) \frac{e^{i k_{q} r}}{r} d V_{x}
\end{aligned}
$$

ここで，入射波の種類を $p$-波 $(p=T, L 1$ または $L 2)$ と して，その入射に対する散乱波における $q$-波の寄与を 示す散乱振幅 $A^{q ; p}$ を次のように定義する。

$$
A_{I}^{q ; p}(\hat{\boldsymbol{y}})=\int_{D} \tilde{g}_{I J}^{q}(\boldsymbol{x}, \hat{\boldsymbol{y}}) B_{J}(\boldsymbol{x}) d V_{x}
$$

この散乱振幅を用いると，散乱場は次のように書ける。

$$
\begin{aligned}
q_{I}^{\mathrm{sc}(\mathrm{far})}(\boldsymbol{y}) & =\sum_{q=T, L 1, L 2} A_{I}^{q ; p}(\hat{\boldsymbol{y}}) \frac{e^{i k_{q} r}}{r} \\
& =\sum_{q=T, L 1, L 2} A_{I}^{q ; p}(\hat{\boldsymbol{y}}) \frac{e^{i \operatorname{Re}\left(k_{q}\right) r}}{r} e^{-\operatorname{Im}\left(k_{q}\right) r}
\end{aligned}
$$

これらの式から, 無限媒質內に物性の不均質な領域が存
する場合に，その不均質部に起团する散乱波の $q$-波成 分の寄与は，等価散乱源 $\boldsymbol{B}$ と基本解の遠方表現 $\left[g_{I f^{f}}\right]$ から求められることがわかる。

\section{BORN 近似による逆問題の定式化}

\subsection{Born 近似}

式 (20)で定義された散乱振幅 $\boldsymbol{A}^{q}$ には，等価散乱源 $\boldsymbol{B}$ の中に散乱体形状に関する関数 $\Gamma(x)$ と散乱体内部での 全変位場 $\boldsymbol{q}$ が含まれる。この全変位場は $\boldsymbol{q}$ は散乱体の 形状の影響を受けるので，式(20)は $\Gamma(x)$ に関する非線 形の方程式であると言える。この方程式を $\Gamma(x)$ に関す る線形の方程式とするために，Born 近似を導入する。 すなわち, 散乱体 $D^{c}$ 内部の変位場 $\boldsymbol{q}=\left\{\boldsymbol{u}^{\mathrm{T}}, p\right\}^{\mathrm{T}}$ が入射 波 $\boldsymbol{q}^{\text {in }}=\left\{\left(\boldsymbol{u}^{\mathrm{in}}\right)^{\mathrm{T}}, p^{\text {in }}\right\} \mathrm{T}$ に等しいと与える。入射波を平面 進行波と仮定して, その伝播方向を示す単位べクトルを $\hat{\boldsymbol{p}}^{\text {in }}$, 粒子変位の万向を示す単位ベクトルを $\boldsymbol{d}^{\text {in }}$ と書いて,

$$
\begin{aligned}
& u_{i}(\boldsymbol{x})=u_{i}^{\text {in }}(\boldsymbol{x})=u_{0} d_{i}^{\text {in }} \exp \left(i k_{p} \hat{\boldsymbol{p}}^{\text {in }} \cdot \boldsymbol{x}\right) \\
& p(\boldsymbol{x})=p^{\text {in }}(\boldsymbol{x})=p_{0} \exp \left(i k_{p} \hat{\boldsymbol{p}}^{\text {in }} \cdot \boldsymbol{x}\right)
\end{aligned}
$$

とする。この近似は，散乱体が入射波の波長に対して十 分小さいときに成立し, 低周波近似と考えることもでき る。

ここで, 散乱波の伝播力向を示す単位べクトルを $\hat{\boldsymbol{p}}^{\mathrm{sc}}$ と書く。すると, 式 (18)で現れる基本解の遠方近似 $\left[\tilde{g}_{I J^{g}}\right]$ は, 定数部分 $\left.\bar{g}_{I I^{q}}\right]$ と指数部分 $\exp \left(-i k_{q} \hat{\boldsymbol{p}}^{\mathrm{sc}} \cdot \boldsymbol{x}\right)$ に分けて, $\tilde{g}_{I J} q=\bar{g}_{I J}{ }^{q} \exp \left(-i k_{q} \hat{\boldsymbol{p}}^{\mathrm{sc}} \cdot \boldsymbol{x}\right)$ の形で書ける。

これらの記号を用いると, 式 $(20)$ は次のように書き 直すことができる。

$$
A_{I}^{q ; p}\left(\hat{\boldsymbol{p}}^{\mathrm{sc}}\right)=\bar{g}_{I J}^{q} \int_{D} \hat{B}_{J}\left(\boldsymbol{x} ; \boldsymbol{q}^{\mathrm{in}}\right) d V_{x}
$$

ここで， $\hat{\boldsymbol{B}}$ は式(16) 及び(17)の等価散乱源 $\boldsymbol{B}$ の表式中

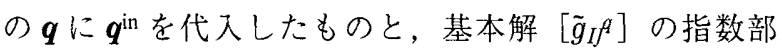
分 $\exp \left(-i k_{q} \hat{\boldsymbol{p}}^{\mathrm{sc}} \cdot \boldsymbol{x}\right)$ の積であり, 次のように書ける。

$$
\hat{B}_{I}=\hat{b}_{I} \Gamma(\boldsymbol{x}) \exp \left\{i \boldsymbol{x} \cdot\left(k_{p} \hat{\boldsymbol{p}}^{\mathrm{in}}-k_{q} \hat{\boldsymbol{p}}^{\mathrm{sc}}\right)\right\}
$$

ここで,

$$
\begin{aligned}
& \hat{b}_{i}=\Delta \tilde{\rho} \omega^{2} u_{0} d_{i}^{\text {in }}+i k_{q}\left(\Delta C_{i j k l} u_{0} d_{k}^{\text {in }} i k_{p} \hat{p}_{l}^{\text {in }} \hat{p}_{j}^{\mathrm{sc}}-\Delta \tilde{\alpha} \hat{p}_{i}^{\mathrm{sc}} p_{0}\right) \\
& \hat{b}_{4}=\Delta\left(\frac{1}{M}\right) p_{0}+i k_{q} \Delta \tilde{\alpha} u_{0} \hat{p}_{k}^{\mathrm{sc}} d_{k}^{\text {in }}-k_{q}^{2} \Delta\left(\frac{1}{\tilde{m}}\right) \frac{1}{\omega^{2}} p_{0}
\end{aligned}
$$

である。次に，散乱波の振動力向を示すべクトル $\boldsymbol{d}^{\mathrm{sc}}$ 定義する。ここで，ベクトル $\boldsymbol{d}^{\mathrm{sc}}$ の中の固体変位に関す る部分 $d_{i}$ は固体の振動方向を示す単位ベクトル $\left(d_{i} d_{i}=\right.$ 1) であり， $d_{4}$ は，散乱波が縦波（L1-波または L2-波） の場合は単位固体变位に対する流体圧力振幅の逆数をと り (Yamamoto and Kitahara, 2004), 横波 (T-波) の 場合は $d_{4}=0$ とする。このベクトル $\boldsymbol{d}^{\text {sc }}$ と式 $(24)$ の雨辺 
との内積をとり，次のように書く。

$$
\begin{aligned}
A_{I}^{q ; p} & \left(\hat{\boldsymbol{p}}^{\mathrm{sc}}\right) d_{I}^{\mathrm{sc}}=\bar{g}_{I K}^{q} \hat{b}_{K} d_{I}^{\mathrm{sc}} \int_{D} \Gamma(\boldsymbol{x}) \exp \{i \boldsymbol{x} \\
& \left.\times\left(k_{p} \hat{\boldsymbol{p}}^{\mathrm{in}}-k_{q} \hat{\boldsymbol{p}}^{\mathrm{sc}}\right)\right\} d V_{x} \\
= & \bar{g}_{I K}^{q} \bar{b}_{I K} \int_{D} \Gamma(\boldsymbol{x}) \exp \left\{i \boldsymbol{x} \cdot\left(k_{p} \hat{\boldsymbol{p}}^{\mathrm{in}}-k_{q} \hat{\boldsymbol{p}}^{\mathrm{sc}}\right)\right\} d V_{x}
\end{aligned}
$$

ここで, 行列 $\left[\bar{b}_{I J}\right]$ は,

$$
\bar{b}_{I J}=\hat{b}_{J} d_{I}^{\mathrm{sc}}
$$

である。これらの表式から，散乱振幅と散乱体の形状を 示す関数 $\Gamma(\boldsymbol{x})$ が定数 $\bar{g}_{I J} q \bar{b}_{I J}$ によって線形に関係づけら れることがわかる。

\section{2 定数項の算出}

ここでは，縱波（L1，L2-波）入射，縱波（L1, L2-波） 観測の場合を考えて, 行列 $\left[\bar{b}_{I J}\right]$ 及び, 定数 $\bar{g}_{I J}{ }^{a} \bar{b}_{I J}$ の具 体的な形を示すことにする。

今，入射波・散乱波双方が縦波の場合には，

$$
d_{i}^{\text {in }}=\hat{p}_{i}^{\text {in }}, d_{i}^{\mathrm{sc}}=\hat{p}_{i}^{\mathrm{sc}}
$$

が成立する。これらを用いて，式(29)で与えられた $\bar{b}_{I J}$ を書き直し, $L 1$-波の場合の基本解の遠方近似 $\tilde{g}_{I J}{ }^{L 1}$ を導 入すると, $L 1$-波散乱に関する比例定数 $\bar{g}_{I J}{ }^{L 1} \bar{b}_{I J}$ は次のよ うに与えられる。

$$
\begin{aligned}
\bar{g}_{I J}^{L 1} \bar{b}_{I J}= & -\frac{1}{2 \pi\left(k_{L 1}{ }^{2}-k_{L 2}{ }^{2}\right)}\left(\frac{1}{\tilde{\rho} \omega^{2}}\right)\left(k_{L 2_{0}}^{2}-k_{L 1}{ }^{2}\right) \\
& \times\left[k_{L 1_{0}}^{2}\left(\frac{\Delta \tilde{\rho}}{\tilde{\rho}}\right)\left(\hat{\boldsymbol{p}}^{\mathrm{in}} \cdot \hat{\boldsymbol{p}}^{\mathrm{sc}}\right) u_{0}-k_{L 1} k_{p} \frac{1}{\lambda+2 \mu}\right. \\
& \times\left\{\Delta \lambda+2 \Delta \mu\left(\hat{\boldsymbol{p}}^{\mathrm{in} \cdot} \cdot \hat{\boldsymbol{p}}^{\mathrm{sc}}\right)^{2}\right\} u_{0} \\
& \left.-i k_{L 1} \frac{\alpha}{\lambda+2 \mu}\left(\frac{\Delta \tilde{\alpha}}{\tilde{\alpha}}\right) p_{0}\right] \\
& +\left[i k_{L 1} k_{L 2_{0}}^{2} \frac{\tilde{\alpha}}{\lambda+2 \mu}\left(\frac{\Delta(1 / M)}{1 / M}\right) p_{0}\right. \\
& -k_{L 1}{ }^{2} k_{Q}{ }^{2}\left(\frac{\Delta \tilde{\alpha}}{\tilde{\alpha}}\right) u_{0}\left(\hat{\boldsymbol{p}}^{\mathrm{in}} \cdot \hat{\boldsymbol{p}}^{\mathrm{sc}}\right) \\
& \left.\left.-i k_{L 1}{ }^{3} \frac{\tilde{\alpha}}{\lambda+2 \mu}\left(\frac{\Delta(1 / \tilde{m})}{1 / \tilde{m}}\right) p_{0}\right]\right)
\end{aligned}
$$

同様に，観測する波がL2-波の場合には，

$$
\begin{aligned}
\bar{g}_{I J}^{L 1} \bar{b}_{I J}= & \frac{1}{2 \pi\left(k_{L 1}^{2}-k_{L 2}^{2}\right)} \cdot\left(\frac{1}{\tilde{\rho} \omega^{2}}\right)\left(k_{L 2_{0}}^{2}-k_{L 2}{ }^{2}\right) \\
& \times\left[k_{L_{1}}^{2}\left(\frac{\Delta \tilde{\rho}}{\tilde{\rho}}\right)\left(\hat{\boldsymbol{p}}^{\text {in }} \cdot \hat{\boldsymbol{p}}^{\mathrm{sc}}\right) u_{0}-k_{L 2} k_{p} \frac{1}{\lambda+2 \bar{\mu}}\right. \\
& \times\left\{\Delta \lambda+2 \Delta \mu\left(\hat{\boldsymbol{p}}^{\mathrm{in}} \cdot \hat{\boldsymbol{p}}^{\mathrm{sc}}\right)^{2}\right\} u_{0} \\
& \left.-i k_{L 2} \frac{\alpha}{\lambda+2 \mu}\left(\frac{\Delta \tilde{\alpha}}{\tilde{\alpha}}\right) p_{0}\right]
\end{aligned}
$$

$$
\begin{aligned}
& +\left[i k_{L 2} k_{L 2_{0}}^{2} \frac{\tilde{\alpha}}{\lambda+2 \mu}\left(\frac{\Delta(1 / M)}{1 / M}\right) p_{0}\right. \\
& -k_{L 2}{ }^{2} k_{Q}^{2}\left(\frac{\Delta \tilde{\alpha}}{\tilde{\alpha}}\right) u_{0}\left(\hat{\boldsymbol{p}}^{\mathrm{in}} \cdot \hat{\boldsymbol{p}}^{\mathrm{sc}}\right) \\
& \left.\left.-i k_{L 2} \frac{\tilde{\alpha}}{\lambda+2 \mu}\left(\frac{\Delta(1 / \tilde{m})}{1 / \tilde{m}}\right) p_{0}\right]\right)
\end{aligned}
$$

が得られる。ここでは，次の波数を用いた。

$$
k_{L 1_{0}}^{2}=\frac{\tilde{\rho}}{\lambda+2 \mu} \omega^{2}, k_{L 2_{0}}^{2}=\frac{\tilde{m}}{M} \omega^{2}, k_{Q}^{2}=\frac{\tilde{m} \tilde{\alpha}^{2}}{\lambda+2 \mu} \omega^{2}
$$

発信器と受信器に同じトランスデューサーを用いる計 測法を Pulse-Echo モードといい, 受信器に発信器とは 別のトランスデューサーを用いて別の方向から計測する 手法をPitch-Catchモードという（Schmerr, 1998）。 Pulse-Echo モードの場合には，入射方向と，観測する 波の伝播方向が逆向きで

$$
\hat{\boldsymbol{p}}^{\mathrm{sc}} \cdot \hat{\boldsymbol{p}}^{\mathrm{in}}=-1
$$

の関係が成り立つ。したがって，この場合の定数項 $\bar{g}_{I J} L 1 \bar{b}_{I J}$ 及び $\bar{g}_{I J}{ }^{L 2} \bar{b}_{I J}$ は次のように書ける。

$$
\begin{aligned}
& \bar{g}_{I J}^{L 1} \bar{b}_{I J}=-\frac{1}{2 \pi\left(k_{L 1}^{2}-k_{L 2}{ }^{2}\right)}\left[-\left(k_{L 2_{0}}^{2}-k_{L 1}^{2}\right)\right. \\
& \times\left\{k_{L 1_{0}}^{2}\left(\frac{\Delta \tilde{\rho}}{\tilde{\rho}}\right) u_{0}+k_{L 1} k_{p}\left(\frac{\Delta \lambda+2 \Delta \mu}{\lambda+2 \mu}\right) u_{0}\right. \\
& \left.+i k_{L 1} \frac{\tilde{\alpha}}{\lambda+2 \mu}\left(\frac{\Delta \tilde{\alpha}}{\tilde{\alpha}}\right) p_{0}\right\}+\frac{\tilde{\alpha}}{\lambda+2 \mu}\left\{i k_{L 1} k_{L 2_{0}}^{2}\right. \\
& \left.\times\left(\frac{\Delta(1 / M)}{1 / M}\right)-k_{L 1}{ }^{3}\left(\frac{\Delta(1 / \tilde{m})}{1 / \tilde{m}}\right)\right\} p_{0} \\
& \left.+k_{Q}^{2} k_{L 1}^{2}\left(\frac{\Delta \tilde{\alpha}}{\tilde{\alpha}}\right) u_{0}\right] \\
& \bar{g}_{I J}^{L 2} \bar{b}_{I J}=\frac{1}{2 \pi\left(k_{L 1}{ }^{2}-k_{L 2}{ }^{2}\right)}\left[-\left(k_{L 2_{0}}^{2}-k_{L 2}{ }^{2}\right)\right. \\
& \times\left\{k_{L 1_{0}}^{2}\left(\frac{\Delta \tilde{\rho}}{\tilde{\rho}}\right) u_{0}+k_{L 2} k_{p}\left(\frac{\Delta \lambda+2 \Delta \mu}{\lambda+2 \mu}\right) u_{0}\right. \\
& \left.+i k_{L 2} \frac{\tilde{\alpha}}{\lambda+2 \mu}\left(\frac{\Delta \tilde{\alpha}}{\tilde{\alpha}}\right) p_{0}\right\}+\frac{\tilde{\alpha}}{\lambda+2 \mu}\left\{i k_{L 2} k_{L 2_{0}}^{2}\right. \\
& \left.\times\left(\frac{\Delta(1 / M)}{1 / M}\right)-k_{L 2}{ }^{3}\left(\frac{\Delta(1 / \tilde{m})}{1 / \tilde{m}}\right)\right\} p_{0} \\
& \left.+k_{Q}^{2} k_{L 2}^{2}\left(\frac{\Delta \tilde{\alpha}}{\tilde{\alpha}}\right) u_{0}\right]
\end{aligned}
$$

Pulse-Echo モードを用いることで，入射波と散乱波の 分離が容易になる。また，散乱波の中のそれぞれの波の 成分を分離することは必ずしも容易でないが，先行して 到達する $L 1$-波と, 後続する $T$-波, $L 2$-波の速度差を利 月して $L 1$-波の主要部分を分離することは可能である。 なお，代表的な砂岩の物性では $L 2$-波の速度は $T$-波と 同程度かより遅くなる。 


\section{3 逆解析}

Born 近似の導入により，式 $(28)$ において散乱体 $D^{\circ}$ の拡がりと散乱振幅 $\boldsymbol{A}^{\mathrm{q}}$ が線形に結ばれた。この式を， 角㓮波数 $\omega$ を陽な形で引数にいれて書き直すと次のよ うになる。

$$
\begin{aligned}
A_{K}^{q ; p}\left(\hat{\boldsymbol{p}}^{\mathrm{sc}}, \omega\right) d_{K}^{\mathrm{sc}} \\
=\int_{D} \bar{g}_{I J}^{q} \bar{b}_{I J} \Gamma(\boldsymbol{x}) \exp [-i s \omega \hat{\boldsymbol{p}} \cdot \boldsymbol{x}] d V_{x} \\
=\int_{D} \bar{g}_{I J}^{q} \bar{b}_{I J} \Gamma(\boldsymbol{x}) \exp [-i \operatorname{Re}(s) \omega \hat{\boldsymbol{p}} \cdot \boldsymbol{x}] \\
\quad \times \exp [\operatorname{Im}(s) \omega \hat{\boldsymbol{p}} \cdot \boldsymbol{x}] d V_{x}
\end{aligned}
$$

ここで， $s \omega \hat{\boldsymbol{p}}=k_{q} \hat{\boldsymbol{p}}^{\mathrm{sc}}-k_{p} \hat{\boldsymbol{p}}^{\mathrm{in}}$ ，また $k_{p}$ は入射波の波数で ある。この形に書き改めると，右辺の未知量は散乱体の 拡がりを示す $\Gamma(\boldsymbol{x})$ のみとなる。

式 (37) が Fourier 変換 $F(\boldsymbol{k})=\int f(\boldsymbol{x}) \exp (-i \boldsymbol{k} \cdot \boldsymbol{x}) d \boldsymbol{x}$ に類似した形をしていることから，逆 Fourier 変換 $f\left((\boldsymbol{x})=1 /(2 \pi)^{3} \int F(\boldsymbol{x}) \exp (i \boldsymbol{k} \cdot \boldsymbol{x}) d \boldsymbol{k}\right.$ を利用して $\Gamma(\boldsymbol{x})$ を求めることができる。

散逸がない $(b=0)$ 場合は波数の虚部 $\operatorname{Im}(s)=0$ であ るため, 式(37)はFourier 変換そのものである。入射波 及び散乱波がともにL1-波または $T$-波である場合は， 虚部は実部に比べて十分小さいので, 散逸の影響は通常 無視できる。したがって，逆 Fourier 変換：

$$
\begin{aligned}
\Gamma(\boldsymbol{x})= & \frac{1}{(2 \pi)^{3}} \oint_{\Theta} \int_{0}^{\infty} \frac{A_{K}^{q ; p}\left(\hat{\boldsymbol{p}}^{\mathrm{sc}}, \omega\right)}{\bar{g}_{I J}^{q} \bar{b}_{I J}} \cdot \frac{d_{K}^{\mathrm{sc}}}{\exp [i s \omega \hat{\boldsymbol{p}} \cdot \boldsymbol{x}]} \\
& \times d \omega d \Theta\left(\hat{\boldsymbol{p}}^{\mathrm{sc}}\right)
\end{aligned}
$$

によって $\Gamma(\boldsymbol{x})$ を定め，形状を再構成することができ る。ここで, $d \Theta$ は微小立体角を示す。

しかし，入射波または散乱波のいずれか，または両方 がL2-波の場合は，波数虚部が無視できないので，式 (37)は Fourier 変換の形から大きくはずれる。入射波の 散逸は小さいが, 散乱波の散逸が大きい場合を考える と，奏際に観測できる散乱波振幅は散逸の影響が含まれ $て A^{q: p} \exp \left[-\operatorname{Im}\left(k_{q}\right) r\right]$ となり，虚部の影響はこの指 数部分に集約できるので, 散乱波逆解析の式を次式で表 すことにする。

$$
\begin{aligned}
\Gamma(\boldsymbol{x})= & \frac{1}{(2 \pi)^{3}} \oint_{\Theta} \int_{0}^{\infty} \frac{A_{K}^{q}\left(\hat{\boldsymbol{p}}^{\mathrm{sc}}, \omega\right) \cdot d_{K}^{\mathrm{sc}}}{\bar{g}_{I J}^{q} \bar{b}_{I J}} \\
& \times \exp [i \operatorname{Re}(s) \omega \hat{\boldsymbol{p}} \cdot \boldsymbol{x}] \\
& \times \exp \left[-\operatorname{Im}\left(k_{q}\right) r\right] d \omega d \Theta\left(\hat{\boldsymbol{p}}^{\mathrm{sc}}\right)
\end{aligned}
$$

式(39)は，L1-波または $T$-波の入射による $L 2$-波の散乱 を観測した場合に適用される。またこの式は空間內の 積分に $\exp \left[-\operatorname{Im}\left(k_{q}\right)\right]$ のウインドウを与えていること に対応するので，各周波数で，波が散逸する以前の中心 から一波長分の範囲を計算対象としているとも言える。

以上により, 各方位・各周波数の散乱振幅 $\boldsymbol{A}^{q}\left(\hat{\boldsymbol{p}}^{\mathrm{sc}}, \omega\right)$ を観測すれば，散乱体の拡がり $\Gamma(\boldsymbol{x})$ を知ることがで
きる。

\section{4. 数值解析で得られた散乱振幅による形状再構成 の事例}

\section{1 解析モデル}

多孔質体中の散乱体の形状を散乱場から求めることが 可能であることを数值的に示すために，数值解析で求め た散乱振幅を用いて形状再構成を試みる。散乱振幅は境 界要素法を利用して得られる (Yamamoto and Kitahara, 2003; Yamamoto and Kitahara, 2004)。

散乱体としては，多孔質弾性体内のキャビティ，及び 多孔質弾性体内の一定の領域の間隙流体が別の流体で置 き換えられた状態を想定して，固体骨格部の物性は变化 せず，その領域の間隙流体の圧縮性のみが周团と異なる インクルージョンがある場合を考える。多孔質弾性体の 4 種類ある弾性定数のうち流体の圧縮性が影響するのは Biot の弾性係数 $M$ のみであり，次のように書くことが できる(Stoll and Bryan, 1970)。

$$
M=\frac{K_{s}^{2}}{K_{s}\left\{1+\beta\left(\frac{K_{s}}{K_{f}}-1\right)\right\}-K}
$$

ここで $K, K_{s}$ 及び $K_{f}$ はそれぞれ固体骨格, 骨格構成粒 子, 及び間隙流体の体積弾性係数であり，構成粒子の圧 縮性と骨格構造の圧縮性が大きく異なる $\left(K_{s} \gg K\right)$ 場合 は,

$$
M=\frac{K_{f}}{\beta}
$$

と近似することができる。そのため，砂岩のようなポー ラスな地層では $M$ は主として間隙流体の圧縮性によっ て定まると言える。したがって，ここでは地層内で間腙 流体の相・成分が異なる領域を， $M$ が周囲（母材）と 異なる領域として扱うことにする。

母材の物性值は, Table 1 に示した数值を用いる。こ れらの值は, Detournay and Cheng (1993) に示されて いる各種砂岩の物性値を参考にして定めた。母材の間隙 は水で飽和した状態であると考え，インクルージョンの 問題ではその一部で間隙流体の体積弾性係数が母:材の

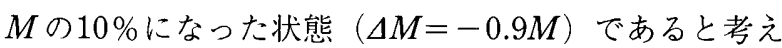
る。

散乱体形状は, 半径 $1 \mathrm{~m}$ の球, 半径が $1 \mathrm{~m}$ の短軸が 回転軸で長軸半径が $1.5 \mathrm{~m}$ である扁平棈付体 (flat ellipsoid），または半径 $1.5 \mathrm{~m}$ の長軸を回転軸とし短軸の半 径が $1 \mathrm{~m}$ である長楕师体（long ellipsoid）のいずれか とし, Fig. 2 に示すように, Pulse-Echoモードで散乱 波を捉えた状態をシミュレートする。ここで，回転軸を $x_{3}$ 軸とし，回転軸からの角度を天頂角 $\theta$ と呼ぶことに する。

送信する波の種類は L1-波であり，受信する波は L1- 
波または L2-波のいずれかとする。

\section{2 再構成の結果}

はじめにインクルージョンの問題を考える。送受信す る波はともにL1-波であり，使用する角周波数 $\omega$ は 2 $\mathrm{krad} / \mathrm{sec} \sim 8 \mathrm{krad} / \mathrm{sec}$ の範囲とする。これは，波長とし ては $7.1 \mathrm{~m}$ から $1.8 \mathrm{~m}$ の範囲に対応し, 散乱体の代表長 $a=1 \mathrm{~m}$ によって無次元化された波数 $a \operatorname{Re}\left(k_{L 1}\right)$ の範囲 では $0.66<a \operatorname{Re}\left(k_{L 1}\right)<2.64$ となる。ここでは散逸がな い $(b=0)$ の場合の散乱振幅を用いた。また，観測は 散乱体の全周で行う。

Fig. 3 及び Fig. 4 に, 扁平楕円体型及び長楕円体型 散乱体の再構成像を示す。これらの図では，回転軸を含

Table 1. Poroelastic parameters used in this paper

\begin{tabular}{|c|l|c|}
\hline Symbols & Definition & Value \\
\hline \hline$\rho$ & Bulk density & $\rho=3000 \mathrm{~kg} / \mathrm{m}^{3}$ \\
\hline$\rho_{f}$ & Fluid density & $\rho_{f}=1000 \mathrm{~kg} / \mathrm{m}^{3}$ \\
\hline$\mu, \lambda$ & Lamé constants & $\mu=\lambda=5.0 \mathrm{GPa}$ \\
\hline$\alpha$ & Biot's constant & $\alpha=1.0$ \\
\hline$\beta$ & Porosity & $\beta=0.2$ \\
\hline$M$ & Biot's modulus & $M=12.5 \mathrm{GPa}$ \\
\hline$b$ & Disspation factor* & $b=1 \times 10^{9} \mathrm{~kg} \cdot \mathrm{m}^{-3} \mathrm{sec}^{-1}$ \\
\hline
\end{tabular}

Dissipation factor $b$ is determined by following equation: $b=\eta / k$ where $k$ : permeability $=1 \times 10^{-12} \mathrm{~m}^{2}, \eta$ :fluid viscosity $=1 \times 10^{-3} \mathrm{~Pa} \cdot \mathrm{sec}$.

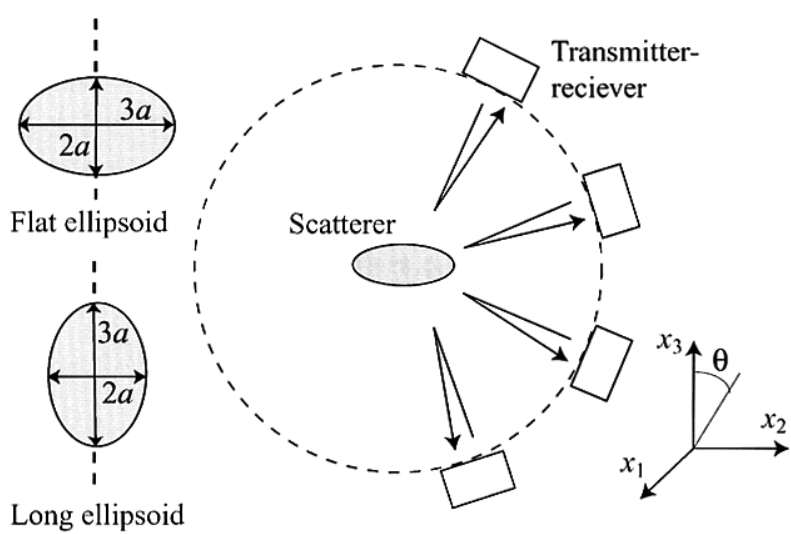

Fig. 2 Configulation of simulated Pulse-Echo mode measurement.
む平面内に扩ける式(39)の $\Gamma(\boldsymbol{x})$ の二次元面内及び三 次元の分布と, $\Gamma(\boldsymbol{x})$ がピークの值の半分の值となる面 で囲んだ再構成像を表示している。また，図中の点線は 散乱体の真の形状を示している。これらの図から，いず れの形状においてもほほ真の形状に近い再構成像が得ら れており，ここで用いた比較的狭い周波数レンジの情報 を元にしても，間隙流体の物性のみが周囲と異なる場合 の形状再構成が弾性体と同様に可能であることが示され た。

\section{3 不完全なデータによる再構成像}

現実の計測においては，散乱体の全周で波を送受信す ることは難しいと考えられる。また，使用できる周波数 の範囲も送受信器の能力やノイズの問題から制約を受け る。このような限られた情報による逆問題は Limited aperture problem と呼ばれるが，これらのデー夕の不 完全性が再構成像に与える影響を調べるため, 式 (39) に打ける空間域及び周波数域の積分範囲と再構成像との 関係を調べる。

\subsection{1 不完全な空間データによる再構成像}

送受信器の設置できる場所が限られた状態を模擬し て, 空間域の積分籁囲を限定しての再構成像を得た。こ こでの計算条件は前節と同じである。

Fig. 5 は，天頂方向（図内の上方）で, 天頂角 $\theta$ が 0 $\leq \theta \leq 30^{\circ}, 0 \leq \theta \leq 60^{\circ}, 0 \leq \theta \leq 90^{\circ}$ の範囲のみから送受信 された場合の再構成 $\left(x_{3}-x_{1}\right.$ 平面内の $\Gamma(\boldsymbol{x})$ の分布) であ る。積分範囲が広くなるほどより実物に近い再構成像が 得られるが，上半全体 $\left(\theta \leq 90^{\circ}\right)$ のデー夕を使えれば実 質的に散乱体の拡がりを正確に捉えることができると言 える。

一方，Fig. 6 は，対称軸を取り柬むように側面から 送受信して, 天頂方向のデータが無い場合の再構成像で あり $, 60^{\circ} \leq \theta \leq 120^{\circ}, 30^{\circ} \leq \theta \leq 150^{\circ}, 10^{\circ} \leq \theta \leq 170^{\circ}$ の三 つのケースについて示している。この場合は，前のケー スょりも再構成像の精度が情報の欠落に豃感である。

いずれのケースでも計測範囲に面していない方向では 再構成像が不明確になるが，このような比較的単純な形 状の問題では使用するデー夕の空間内の一部が失われて も，おおまかな広がりは依然捉えられていることがわか る。しかし, 正確な再構成を行うには, 対象の形状を特 徵付ける軸方向のデータが揃っている必要がある。

\subsection{2 周波数带域と再構成精度}

これまでは比較的狭い周波数レンジを使用しても一定 の再構成像が得られることを示したが,ここでは得られ た再構成像の精度と周波数の関係をやや定量的に示す。

ここでは半径 $1 \mathrm{~m}$ の球形のキャビティを対象として, L1-波を送受信する場合を考える。キャビティのモデル は，すべての多孔質弾性パラメー夕について， $\Delta \phi=-\phi$ であるとして再構成像を求めた。積分する角周波数 $\omega$

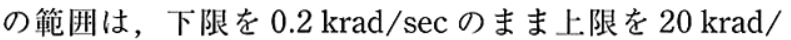




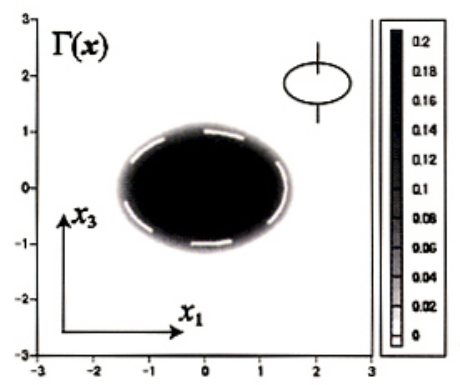

(a) Distribution of $\Gamma(x)$ in $x_{3}-x_{1}$ plane.

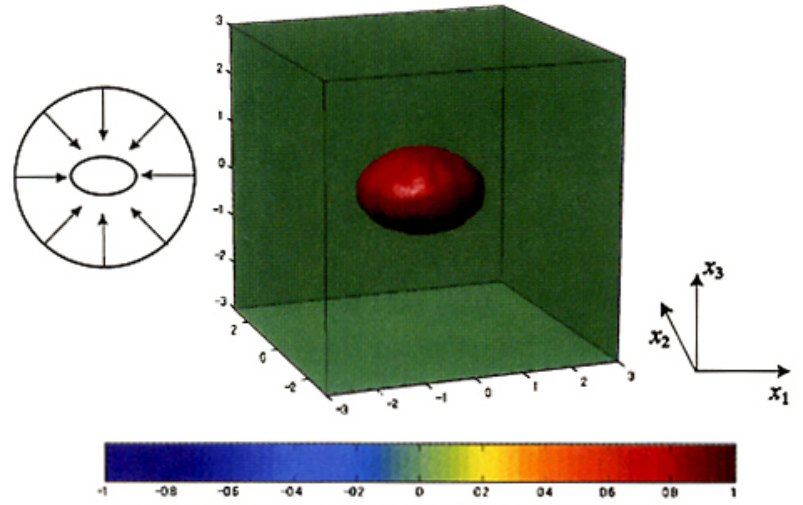

(b) Isopleth surface on which $\Gamma(x)$ is $50 \%$ of its peak value.

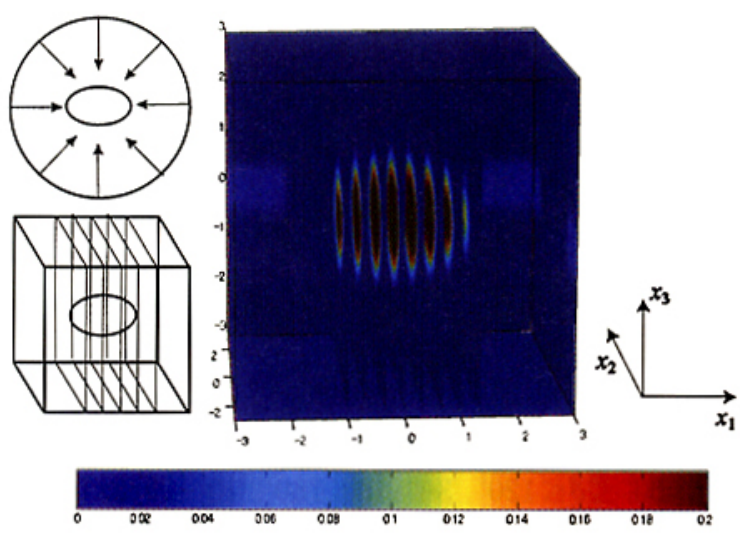

(c) Sliced image of $\Gamma(x)$ on $x_{1}=$ constant planes.

Fig. 3 Reconstructed image of a flat ellipsoid, $\Delta M=-$ $0.9 M$.

sec まで変化させる。この時の各周波数における散乱振 幅を Fig. 7 に示す。この時の無次元化波数は $0.0897 \leq$ $a \operatorname{Re}\left(k_{L 1}\right) \leq 8.97$ の籁囲である。 $a \operatorname{Re}\left(k_{L 1}\right)<1$ の笓囲で 散乱振幅は単調增加するが, それ以上の周波数では幾つ かのピーク周波数を持って変化する。

再桴成像の周波数依存性は Fig. 8 に示す。ここでは, $x$-軸上の $\Gamma(\boldsymbol{x})$ の分布を示しており，真の値は太実線で 示されるように $|x|<1$ では $\Gamma(\boldsymbol{x})=1$, それ以外では 0 となる。

再㮐成されるべき $\Gamma(\boldsymbol{x})$ に比べると，最高周波数が $16 \mathrm{krad} / \mathrm{sec}$ までは, 高周波のデータまで使用した結果 の方が，階段関数状である本来の $\Gamma(\boldsymbol{x})$ に近いことが

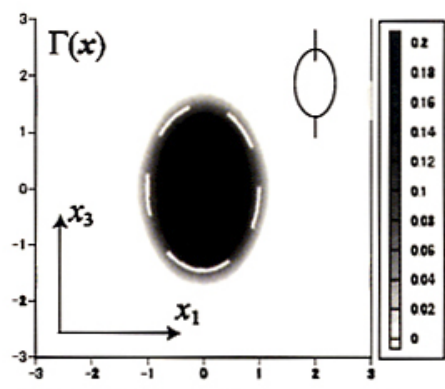

(a) Distribution of $\Gamma(x)$ in $x_{3}-x_{1}$ plane.

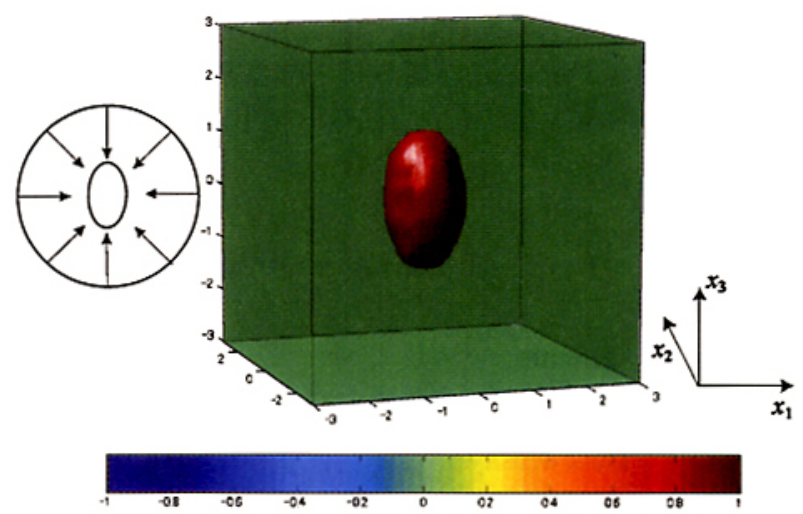

(b) Isopleth surface on which $\Gamma(x)$ is $50 \%$ of its peak value

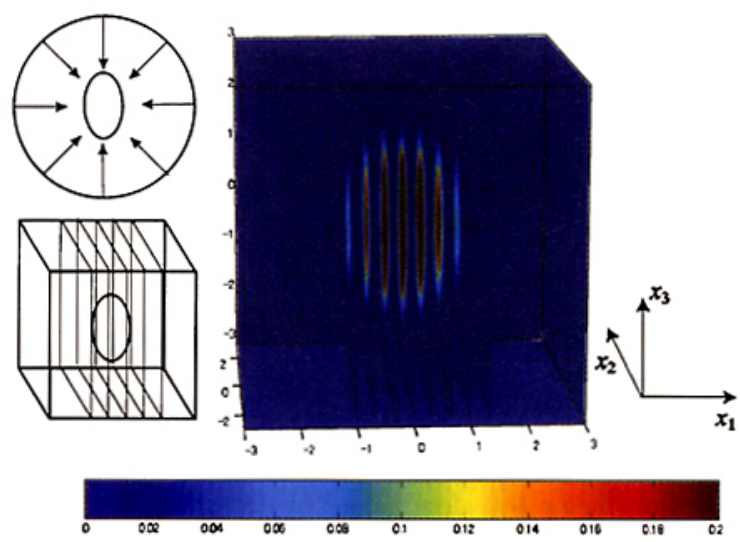

(c) Sliced image of $\Gamma(x)$ on $x_{1}=$ constant planes.

Fig. 4 Reconstructed image of a long ellipsoid, $\Delta M=-$ $0.9 M$.

わかる。したがってより高い周波数まで利用すれば精度

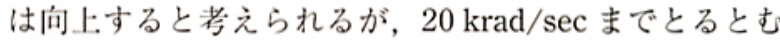
しろ愦差が搪大している。これは，周波数が高すぎると Born 近似が成立しなくなることが一つの理由と考えら れる。また，低周波のみを使用した場合も，散乱体のお おまかな搪がりは示されているといえる。

\section{4 散逸の影響がある場合-遅い縦波の受信}

これまでの例では, 散逸の影㟙が小さい $L 1$-波の入射 及び瓶乱による形状再模成の例を見てきたが，ここでは 散逸の影䇾が大きく現れる遅い縦波である L2-波の散乱 を钼测する場合の形状再構成の事例を見る。人射波はこ 

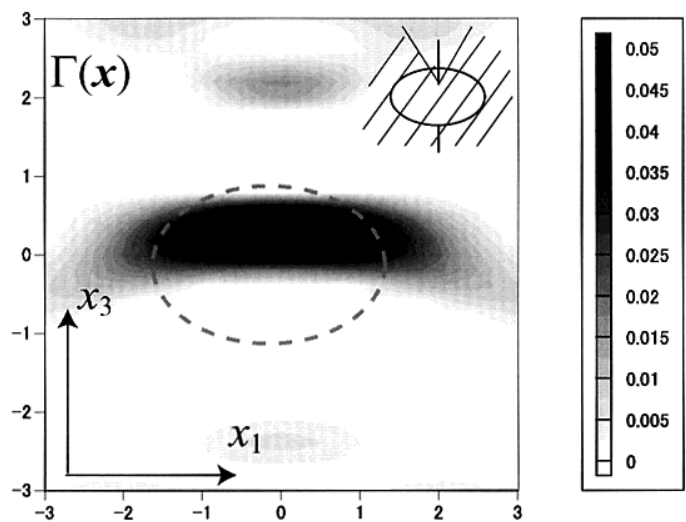

(a) $\theta<30 \mathrm{deg}$
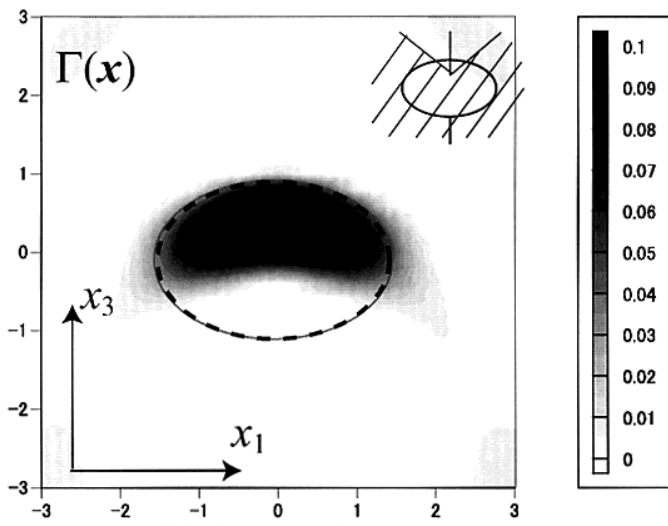

(b) $\theta<60 \mathrm{deg}$

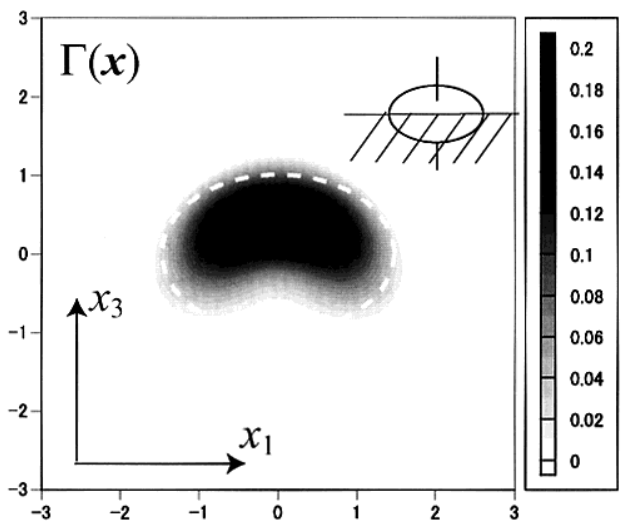

(c) $\theta<90 \mathrm{deg}$

Fig. 5 Reconstructed image of a flat ellipsoid by the data of upper spaces $\left(\Gamma(\boldsymbol{x})\right.$ distribution in $x_{3}-x_{1}$ plane $)$.

れまでと同じく $L 1$-波である。

ここでは回転楕円体のキャビティの問題を考える。使 用した角周波数は $0.2 \mathrm{krad} / \mathrm{sec}$ から $16 \mathrm{krad} / \mathrm{sec}$ で, キャビティの代表長 $a=1 \mathrm{~m}$ によって無次元化された波 数で示すと, $L 1$-波については, $0.066 \leq a \operatorname{Re}\left(k_{L 1}\right) \leq$ $5.26,7.28 \times 10^{-6} \leq a \operatorname{Im}\left(k_{L 1}\right) \leq 1.33 \times 10^{-2}, L 2$-波につい ては, $0.775 \leq a \operatorname{Re}\left(k_{L 2}\right) \leq 13.7,0.757 \leq a \operatorname{Im}\left(k_{L 2}\right) \leq 3.41$ である。Biotのモデルでは, 散逸の効果は散逸定数 $b$ に関係する臨界周波数 $\omega_{c}=b \beta / \rho_{f}($ Biot, 1956) より低い 範囲で顕著となるが, ここでは $\omega_{c}$ は周波数の上限と下

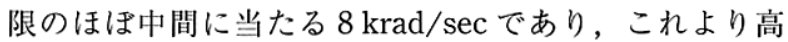

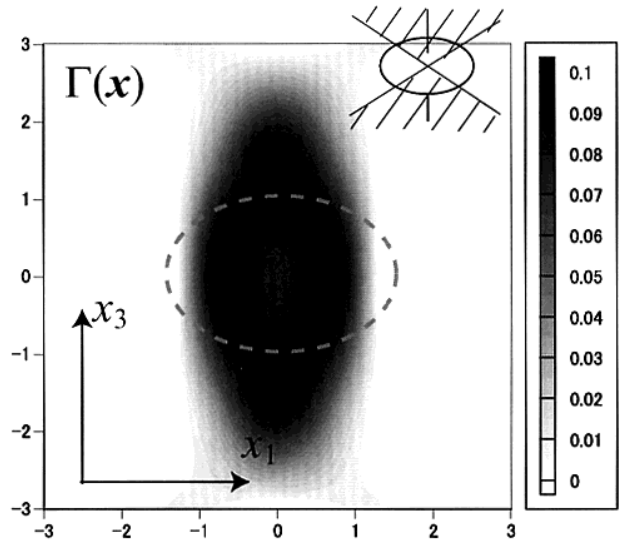

(a) $60 \mathrm{deg}<\theta<120 \mathrm{deg}$
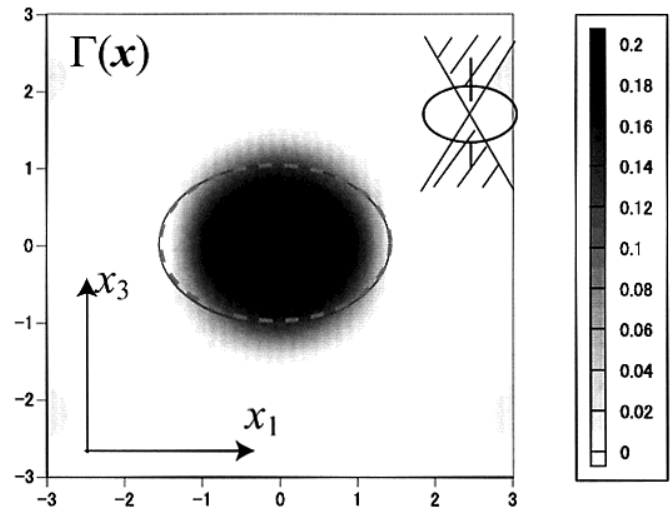

(b) $30 \mathrm{deg}<\theta<150 \mathrm{deg}$

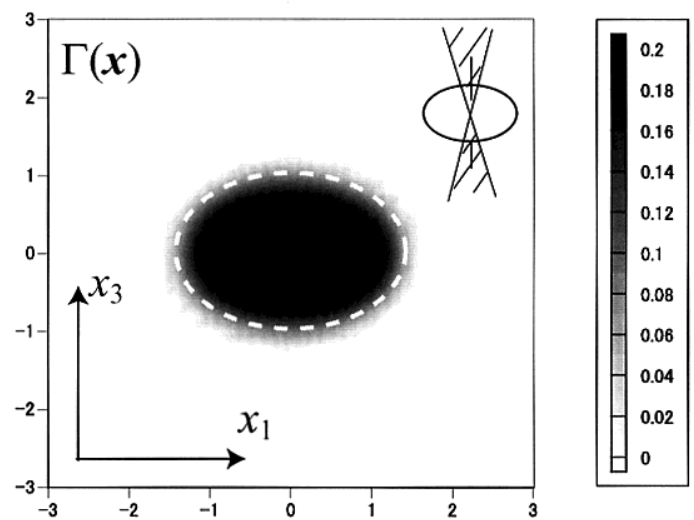

(c) $10 \mathrm{deg}<\theta<170 \mathrm{deg}$

Fig. 6 Reconstructed image of a flat ellipsoid by the data around the symmetric axis $\left(\Gamma(\boldsymbol{x})\right.$ distribution in $x_{3}$ $-x_{1}$ plane).

い周波数域を使用した場合（高周波数域， $\omega \geq \omega_{c}$ ），低 い周波数域を使用した場合（低周波数域， $\omega \leq \omega_{c}$ ) のそ れぞれについて再構成像を求めることにする。

再構成された平面棈円体及び長楕円体の像を Fig. 9 及び Fig. 10 に示す。それぞれの図において，高周波数 域を利用した場合と低周波数域を利用した場合のそれぞ れの像を図示している。この結果から, 散逸が無視でき ない場合では入射波・散乱波ともに $L 1$-波の場合と比べ ると実際の形状との差が大きいが，おおまかな拡がりと 


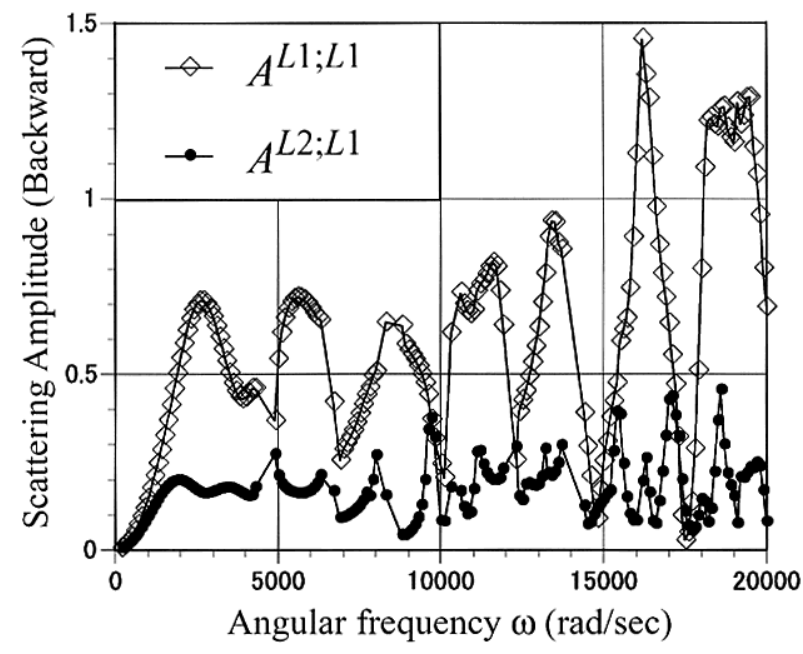

Fig. 7 Scattering amplitude of $L 1$-and $L 2$-wave scattering $\left(A^{L 1 ; L 1}, A^{L 2: L 1}\right)$ in each frequency. Spherical cavity case.

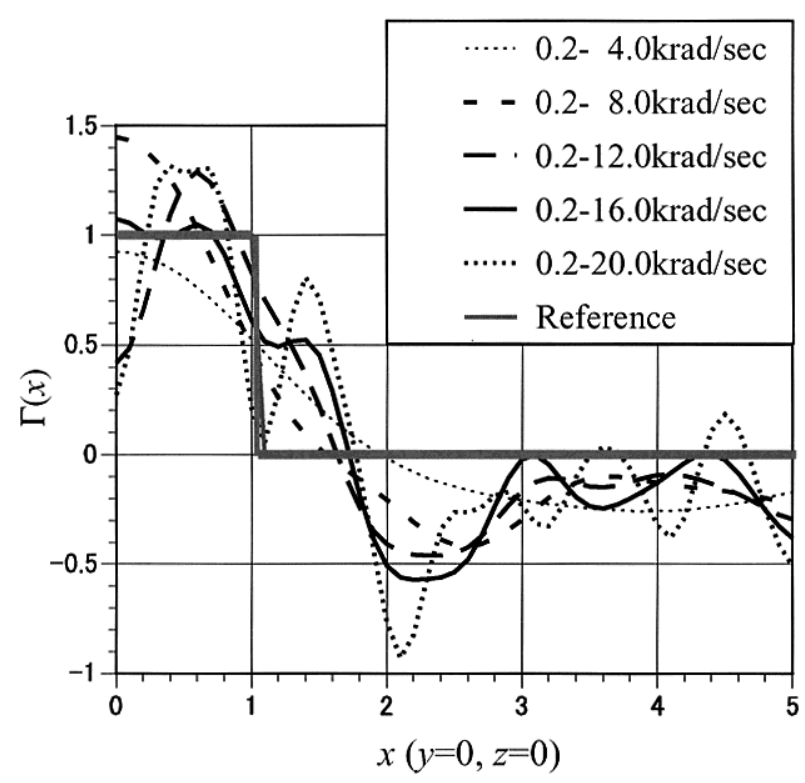

Fig. 8 Dependency of the reconstructed image on used frequency range $\left(\Gamma(\boldsymbol{x})\right.$ distribution on $x_{1}$-axis).

形状が計算されていることがわかる。ただし，長棈円体 で高周波成分のみを使った場合，低周波と同じ $\Gamma(\boldsymbol{x})$ の值の点を結ぶ面で作成した再構成像は元の形状とは大 きく異なり，高い䛊差のピークが生じる中心付近にしか 值が現わ机ないため，より小さな值に修正して表示して いる。このように, $\Gamma(\boldsymbol{x})$ の閾值の設定により再構成像 が任意性を持つことは本手法の一つの問題点といえる。

なお，臨界周波数より高い周波数を用いる方が散逸の 影響は小さいが，一方で高周波では波長が短くなるため 低周波近似が成り立たなくなり，特に音速の逑い $L 2$-波 の波長は入射波の $L 1$-波に比べて短いため, 誤差の要因 となりやすいと考えられる。そのため, 高周波と低周波 いずれが有利かは一概には言えない。
実際には $L 2$-波は隇衰が大きいため計測が難しく，ま た先に到達する $L 1$-波から $L 2$-波のみを分雖することは 困難なので, 実用上この波が形状再構成に用いられるこ とは考えにくいが，ここで示した数值例によって，散逸 の影響があっても形状再構成が可能であることが示され た。

\section{5. まとめと課題}

領域型積分を用いた散乱振幅の表現とBorn 近似を用 いた逆解析手法により, 形状の再構成が Biot の飽和多 孔質体中でも実現できることを, 数值計算による散乱振 幅を用いて示した。この手法では, 比較的狭い周波数レ ンジの散乱振幅のデータでも一定の精度で形状を再現で きること, 及び計測データの得られる方向が限られてい ても，ある程度散乱体の広がりを捉えることができるこ とを示した。

本手法は，比較的低周波の弾性波を用いるため，送信 のパワーを大きくできる，空間内の小さなスケールの非 均質性の影響を受けにくい等の利点がある。数值計算上 は, 一般の逆解析で生じる, 解の一意性が保証されない ことや，収束性と得られる解が初期值に依存すること， また一般的に収束までの時間が亜大になりうることなど の問題を解決することができる。

一方で, 本手法の基盤となっている，均質な場におけ る弱い散乱体の仮定が現実の非均質な材料に適用できる のかという課题が存在する。この問題については, 定式 化と計測デー夕の処理の両方のアプローチで解決するこ とが必要であるが, Nakahata and Kitahara (2000) は 完全反射面からの反射を参照波としてそれと計測した波 の差から散乱波の成分を抽出することで媒質の影響を取 り除く手法を開発し，この手法で非均質なコンクリート 中での散乱体の形状を再構成することに成功している （山田ら，2003）。さらに，参照波を均質材料から擬似 的に作成するデー夕处理手法も適用されて成功している (山田ら，2004)。このように，対象散乱体サイズより も小さなスケールの不均質部については，低周波近似の 有利性から, デー夕処理法の向上により解決可能と思わ れる。しかし，地層境界の存在のようなより大きなスケ 一ルの非均質性については, 均質な媒質中の散乱体とい う前提が崩れるため, デー夕処理のみでは対処できず, 定式化を含めた今後の検討が必要である。

ここで示した数值計算例によって, 二酸化炭素の地中

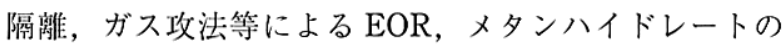
分解領域など，間隙流体の挙動が主たる関心である場合 の探查・モニタリングに本手法が適用できる可能性が示 された。多孔質体への適用という観点では, 実際の地層 の岩石に対する Biot モデルの適用性の検証も課題であ る。

今後, 定式化と数值計算技術に加えて, 計測技術及び デー夕处理手法の向上をはかり，本手法がより現実の材 


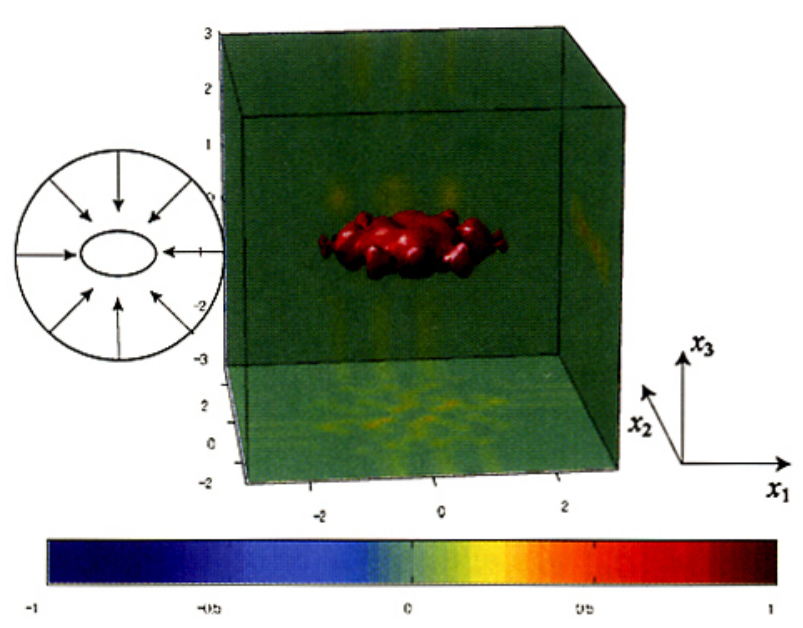

(a) Low frequency range $\left(\omega<\omega_{c}\right)$

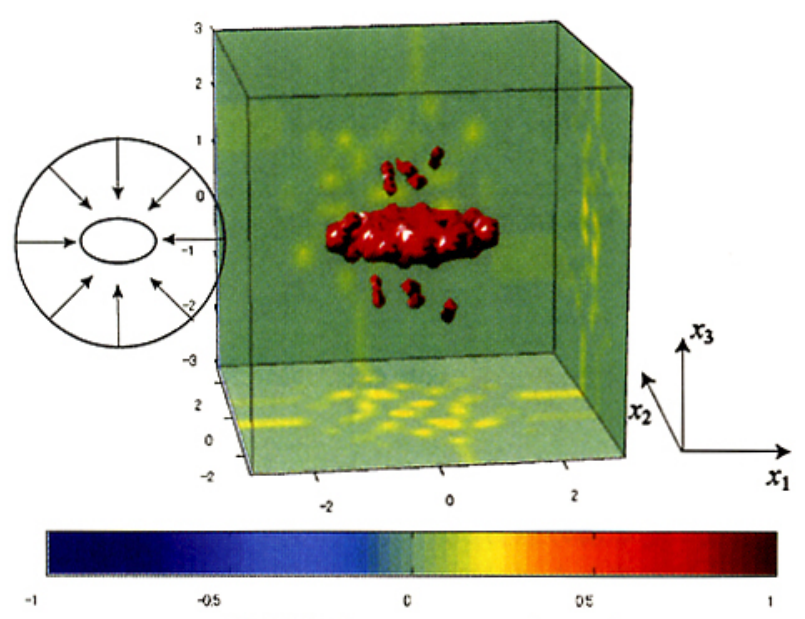

(b) High frequency range $\left(\omega>\omega_{c}\right)$

Fig. 9 Reconstructed image by the scattering amplitud of L2-wave. A flat ellipsoide (Isopleth surface on which $\Gamma(\boldsymbol{x})$ is $10 \%$ of their peak values).

料，現実の場の問題に適用できるものとなるように研究 を進めたい。

\section{謝 辞}

本研究においては, 東京工業大学大学院悄報理工学研 究科の廣濑壮一教授, 爱嫒大学工学研究科の中烟和之講 捄, 東北大学大学院工学研究科の岸野裉次教授, 寺田賢 二郎助教授，山田真幸助手のご指導をいただきました。 ここに感謝申し上げます。また本論文の其著者である東 北大学大学院工学研究科の北原道弘教授は2003年11月 に逝去されました。ここに先生のご冥福を书祈りすると ともに，御家族に哀悼の意を表します。また，雚名の二 名の查読省より有益なご示唆をいただきました。重极て 感謝します。

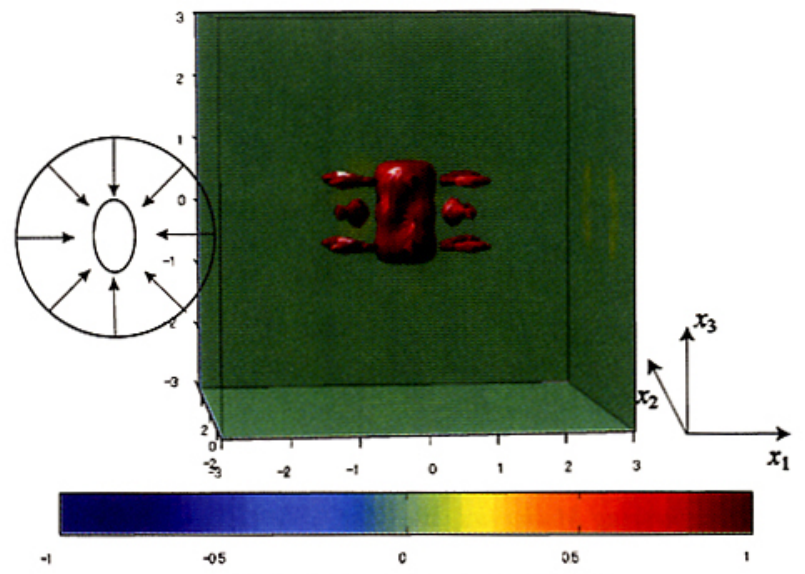

(a) Low frequency range $\left(\omega<\omega_{c}\right)$

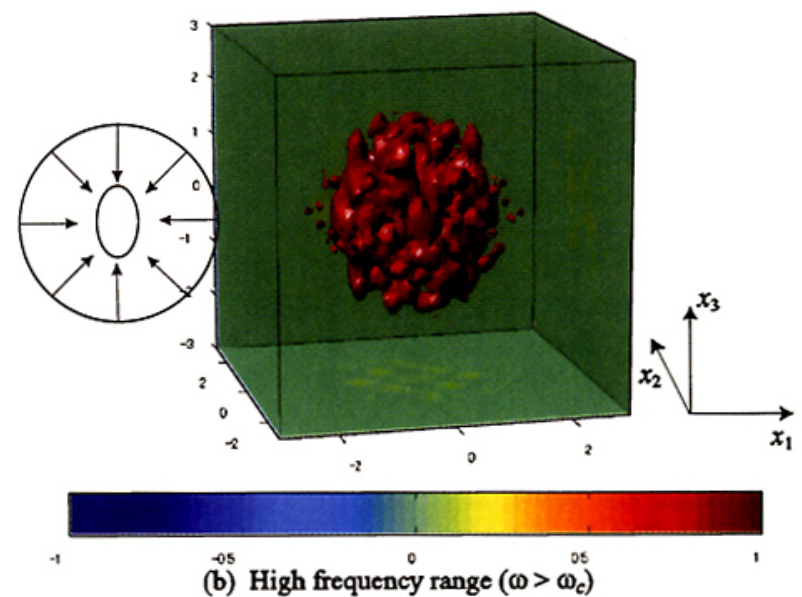

Fig. 10 Reconstructed image by the scattering amplitud of $L 2$-wave. A long ellipsoide (Isopleth surface on which $\Gamma(\boldsymbol{x})$ is $10 \%$ (low frequency) and $3 \%$ (high frequency) of their peak values).

\section{参 考 文 献}

Bauer, K., Pratt, R. G., Weber M., Ryberg, T., Haberland, C. and Shimizu, S. (2004) : Mallik 2002 cross-well seismic experiment: project design, data acquisition, and modelling studies, Dallimore, S. R. and Collett, T. S. eds. Scientific Results from the Mallik 2002 Gas Hydrate Produc-tion Research Well Program, Mackenzie Delta, Northwest Territories, Canada, Geological Survey of Canada Bulletine 585 .

Biot, M. A. (1956) : Theory of propagation of elastic waves in a fluid-saturated porus solid. I. Low-frequency range, $J$. Acoust. Soc. Am., 28, 168-178.

- and Willis, D. G. (1957) : The elastic coefficients of the theroy of consolidation, J. Appl. Mech., 24, 594-601.

- (1962): Mechanism of deformation and acoustic propagation in Porous Media, J. Appl. Phys., 33, 14821498.

Cheng, A. H.-D., Badmus, T. \& Beskos, E. (1991) : Integral equation for dynamic poroelasticity in frequency domain with BEM solution, J. Eng. Mech. ASCE, 117, 1136-1157.

Detournay. E. and Cheng, A. H.-D. (1993) : Fundamental poroelasticity, Comprehensive Rock Engineering:Principles, Practice, and Projects, Vol. 2 Analysis and Design 
Methods, eds. C. Fairhurst, 113-171, Pergamon Press, Oxford.

Dominguez, J. (1992) : Boundary element approach for dynamic poroelastic problems. Int. J. Numer. Meth. Eng., 35, 307-324.

福井卓雄・船戸慶輔・井上耕一 (1996)：Biot 物体中に打ける 波動問題の周波数領域境界要素法解析，境界要素法論文集， JASCOM, 13, 149-152.

Hsu, D. K., Rose, J. H. and Thompson, D. O. (1984) : Reconstruction of inclusions in solids using ultrasonic Born inversion, J. Appl. Phys., 55, 162-168.

Kitahara, M. and Hirose, S. (1998) : Elastodynamic inversion of $3 \mathrm{D}$ caviy from backscattering data, Inverse Problems in Engineering Mechanics, Elsevier. 163-170.

_ - Nakahata, K. and Hirose, S. (2002) : Elastodynamic inversion for shape reconstruction and type classification of flaws, Wave Motion, 36, 443-455.

狐崎長琅（2004）：管の波からみた流体飽和多孔質媒質の縦波 弾性波 (2004)：Biot 理論の単.純化モデル，物理探查，57, 151-172.

LaPorte, M., Lakshmanan, J., Lavergne, M. and Willim, C. (1973) : Seismic measurements by transmission-Application to civil engineering, Geophys. Prosp., 21, 146-158.

宮腰宽之・山田真幸 (2005)：計測波形を用いた三次元線形化 逆散乱解析による任意形状欠陥の再構成，第54回理論応用 力学講演会講演論文集, 日本学術会議, 83-84.

Nakahata, K. and Kitahara, M. (2000) : Shape reconstruction methods with incomplete data, Review of Progress in Quanitative Nondestructive Evaluation, 27, 919-926.

Nur, A. M. and Wang, Z. (1987) : In situ seismic monitoring EOR: The petrophysical basis. SPE16865, Proc. 62nd Annual Technical Conference and Exhibition of the Society of Petroleum Engineers, Dallas, TX, 307-314.

大下敏哉（2002）：枯渇油・ガス田の有効利用，石油技術協会 誌, 67, 538-546.

Pratt, R. G. \& Worthington (1990) : Inverse theory applied to multi-source cross-hole tomography. Part 1: Acoustic wave-equation method, Geophys. Prosp., 38, 287-310.

- (1999) : Seismic waveform inversion in the frequency domain, Part 1: Theory and verification in a physical scale model, Geophysics, 64, 888-901.

Rose, J. H. and Opsal, J. L. (1982) : Inversion of ultrasonic scattering data, Review of Progress in Quanitative Nondestructive Evaluation, 1, 187-195.

_- (1984) : Exterioir reconstruction of a three-dimensional scatterer, Wave Motion, 8, 149-154.

Schmerr, L. W., Sedov, A. and Chiou, C. P. (1989) : A unified constrained inversion model for ultrasonic flaw sizing, Res. Nondestr. Eval, 1, 77-97.

- (1998) : Fundamentals of Ultrasonic Nondestructive Evaluation -A Modeling Approach, Plenum Press, New York.

Stoll, R. D. and Bryan, G. M. (1970) : Wave attenuation in saturated sediments, J. Acoust. Soc. Am., 5, 1440-1447.

山田真幸 ·村上賢治 -中烟和幸 · 北原道弘 (2003) : 円柱側面 からの計測波形による三次元欠陥像の再構成，応用力学論 文集, 土木学会，6,69-76.

—. る非均質材料内の欠陥形状再構成, 忘用力学論文集, 土木 学会, 7, 83-90.
Yamamoto, K. and Kitahara, M. (2003) : Characterization of scatterers in poroelastic media using far field integral representation, Proc. 16th Engineering Mechanics Con-ference, ASCE, Seattle, Washington.

_ - a and Kitahara, M. (2004) : A numerical method for wave scattering in poroelastic media, Structural Eng./Earthquake Eng., JSCE, 21, 143s-158s.

横田俊之. 西田明夫 ·溝畑茂治 - 島田伸介 . 村岡直 (2003)：石油 EOR における貯留層内流体挙動の把握一初 動走時トモグラフィーを用いたモニタリング一，物理探査， 56, 181-189.

\section{補遺-1：多孔質弾性体の基本解}

基本解 $\left[G_{I J}\right]$ の具体的表現：

$$
\begin{aligned}
G_{i j}= & \frac{1}{4 \pi \mu}\left[\frac{e^{i k_{T} r}}{r} \delta_{i j}+\frac{1}{k_{L 1}{ }^{2}-k_{L 2} 2} \frac{\partial}{\partial x_{i}} \frac{\partial}{\partial x_{j}}\left\{\frac{k_{L 1_{0}}^{2}-k_{L 2}^{2}}{k_{T}^{2}}\right.\right. \\
& \left.\left.\times\left(\frac{e^{i k_{r} r}}{r}-\frac{e^{i k_{L 1} r}}{r}\right)-\frac{k_{L 1_{0}}^{2}-k_{L 1}^{2}}{k_{T}^{2}}\left(\frac{e^{i k_{r} r}}{r}-\frac{e^{i k_{L 2} r}}{r}\right)\right\}\right] \\
G_{i 4}= & -\frac{k_{Q}^{2}}{4 \pi \tilde{\alpha}} \frac{1}{k_{L 1}^{2}-k_{L 2}{ }^{2}} \frac{\partial}{\partial x_{i}}\left(\frac{e^{i k_{L 1} r}}{r}-\frac{e^{i k_{L 2} r}}{r}\right) \\
G_{4 j}= & \frac{k_{Q}^{2}}{4 \pi \tilde{\alpha}} \frac{1}{k_{L 1}{ }^{2}-k_{L 2}} \frac{\partial}{\partial x_{i}}\left(\frac{e^{i k_{L 1} r}}{r}-\frac{e^{i k_{L 2} r}}{r}\right) \\
G_{44}= & -\frac{M}{4 \pi} k_{L 2_{0}}^{2} \frac{1}{k_{L 1}{ }^{2}-k_{L 2}{ }^{2}}\left\{\left(k_{L 1_{0}}^{2}-k_{L 1}^{2}\right) \frac{e^{i k_{L 1} r}}{r}\right. \\
& \left.-\left(k_{L 1_{0}}^{2}-k_{L 2}^{2}\right) \frac{e^{i k_{L 2} r}}{r}\right\}
\end{aligned}
$$

\section{補遺-2：基本解の遠方表現}

基本解の遠方表現 $\left[\tilde{g}_{I J}(\boldsymbol{x}, \hat{\boldsymbol{y}})\right]$ の具体的表現：

$$
\begin{aligned}
& {\left[\bar{g}_{i j}{ }^{T}\right]=\left[\begin{array}{cc}
\frac{1}{4 \pi \mu}\left\{\delta_{i j}+k_{T}{ }^{2}\left(\hat{y}_{i} \hat{y}_{j}\right)\right\} & 0 \\
0 & 0
\end{array}\right] e^{-i k_{T} x \cdot \hat{y}}} \\
& {\left[\bar{g}_{i j}^{L 1}\right]=\frac{1}{k_{L 1}{ }^{2}-k_{L 2}{ }^{2}}\left[\begin{array}{c}
-\frac{1}{4 \pi \mu} \frac{k_{L 1}{ }^{2}\left(k_{L 1_{0}}^{2}-k_{L 2}{ }^{2}\right)}{k_{T}^{2}}\left(\hat{y}_{i} \hat{y}_{j}\right) \\
\frac{k_{Q}{ }^{2}}{4 \pi \tilde{\alpha}} i k_{L 1}\left(\hat{y}_{j}\right)
\end{array}\right.} \\
& \left.\begin{array}{c}
-\frac{k_{Q}^{2}}{4 \pi \tilde{\alpha}} i k_{L 1}\left(\hat{y}_{i}\right) \\
-\frac{M}{4 \pi} k_{L 2_{0}}^{2}\left(k_{L 1_{0}}^{2}-k_{L 1}^{2}\right)
\end{array}\right] e^{-i k_{l, 1} x \cdot \hat{y}} \\
& {\left[\bar{g}_{i j}{ }^{L 2}\right]=\frac{1}{k_{L 1}{ }^{2}-k_{L 2}{ }^{2}}\left[\begin{array}{c}
\frac{1}{4 \pi \mu} \frac{k_{L 2}^{2}\left(k_{L 1}^{2}-k_{L 1}^{2}\right)}{k_{T}^{2}}-\left(\hat{y}_{i} \hat{y}_{j}\right) \\
-\frac{k_{Q}^{2}}{4 \pi \tilde{\alpha}} i k_{L 2}\left(\hat{y}_{j}\right)
\end{array}\right.} \\
& \left.\begin{array}{c}
\frac{k_{Q}^{2}}{4 \pi \tilde{\alpha}} i k_{L 2}\left(\hat{y}_{i}\right) \\
\frac{M}{4 \pi} k_{L 2_{0}}^{2}\left(k_{L 1_{0}}^{2}-k_{L 2}^{2}\right)
\end{array}\right] e^{-i k_{L 2} x \cdot \hat{y}}
\end{aligned}
$$

